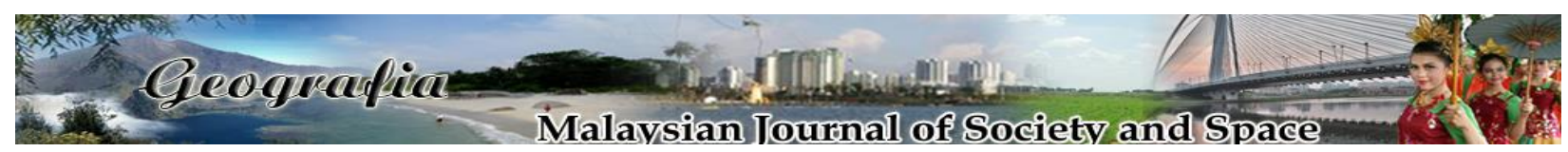

\title{
Malaysia towards an ageing country
}

\author{
Nik Norliati Fitri Md Nor ${ }^{1}$, Suriati Ghazali ${ }^{2}$ \\ ${ }^{1}$ Geography Section, School of Distance Education \\ ${ }^{2}$ Geography Section, School of Humanities \\ Universiti Sains Malaysia \\ 11800 Penang, Malaysia.
}

Correspondence: Nik Norliati Fitri Md Nor (email: nikfitri@usm.my)

Received: 01 April 2021; Accepted: 19 July 2021; Published: 27 August 2021

\begin{abstract}
An increase in the number of the elderly population (aged 60 and above) is a global phenomenon, specifically in the developed and developing countries. This is due to development in terms of socioeconomic status such as improved education, healthcare, employment, increasing life expectancy, as well as decreasing fertility and mortality rate of these countries. In fact, Malaysia also has had an increase in population growth and will become an ageing country by 2030 . Statistics show that there is an increase in the number of elders aged 60 and above, while the percentage of the young people aged 14 and below decreases over the years. The growing number of elders results in socioeconomic and political issues in these countries due to healthcare costs, as well as economic, physical, and social support from family members, community and policymakers in terms of living arrangements. This article will discuss about some policies and planning with regards to the elders, but the author shall focus on policies and planning related elderly support from their family, especially from the children. This article secondary sources such as previous studies, statistical data on the improvement of the elders, newspapers and official websites. It is aimed to help the Malaysian government in reviewing the current policies and further focus on strategies and plans that require the children to support their elders and prevent the issue of elderly neglect as being highlighted in the news.
\end{abstract}

Keywords: ageing, children support, elders, healthcare, Malaysia, quality of life

\section{Introduction}

The increase in the elderly population indicates socioeconomic progress and demographic changes in the increasingly developed society. However, the growth of the ageing population has significant implications on the need for care, financial resources, and facilities to improve their wellbeing and quality of life (Nur Syakiran, et al., 2017). This leads to the increase in retirement age and the of elderly dependents. For example, in Malaysia due to the elderly population growth, 
the government has extended the mandatory retirement age from 58 to 60 during 2012 Budget on $7^{\text {th }}$ October 2011 (Ministry of Finance Malaysia, 2014). Moreover, the impacts of the elderly population growth on the economy, social support, and healthcare of the countries involved raise a concern. To ensure the wellbeing of the senior citizens, more physicians are required to provide geriatric care in the government and private hospitals. The former Minister of Family, Women and Community Development, Dato' Seri Rohani Abdul Karim said Malaysia needs to prepare at least 700 geriatricians and specialists 2020 to accommodate the increasing elderly population (Berita Harian, 12.8.2015). The social welfare system to care for the elders must be fulfilled so that they can lead a prosperous and healthy life (Berita Harian, 21.5.2015). This article will look at the growth trend of the elderly countries in developing countries, including Malaysia, as well as policies related to the elders in country, that involve support from family members of the elders. Some of the elders who have neglected were featured in the newspapers. The authors hope Malaysia can come up with policies and legal action to be imposed on children who do not want to care for their parents.

\section{The trend of ageing population in developing countries}

Nowadays, the rate of population aging increases rapidly over the years, especially in the industrial countries. According to the United Nations (2019), the percentage of people aged 65 and above was $9.1 \%$ while the life expectancy at birth was 72.9 in 2019. Life expectancy at birth refers to the average period (in years) that a newborn is expected to live (Department of Statistics Malaysia, 2018). Besides, population percentage of people aged 65 and above in the developed, developing, and least developed regions in 2019 was $18.9 \%, 7.2 \%$ and $3.6 \%$, respectively (United Nations, 2019). Ageing process a huge challenge in the Asian countries since there were $53 \%$ of the elders in this word live on this continent, particularly in Japan, China, and India (Dhillon et al., 2016). ASEAN countries such as Cambodia, Singapore, Thailand, Vietnam are dealing with increasing wlderly population (aged 65 and above). In fact, elderly population is projected to increase to $26.6 \%$ in Singapore and 22.8\% in Thailand by 2035 (New Straits Times, 2019). In fact, a country is deemed as an 'old' country when $8 \%$ of its population are 65 years old and above. However, according to the United Nations (UN), a country is deemed as an ageing country if the those who aged 65 and above make up 15\% of the population (United Nations, 2011).

According to the UN, almost $81 \%$ of the world elderly population in 2050 will be from the developing countries (2011). This raises a concern in the aspects of socioeconomic status, health, healthcare, housing, and politics. The elderly population growth is significant on socioeconomic progress and demographic changes in the developing countries. However, the increase in the number of elders poses a challenge in geriatric care, financial resources, and facilities. Since the number of elders in developing countries increases, this leads to increased retirement age and oldage dependency ratio. According to Matras (1977), population ageing is due to the increased ratio of elderly persons, while the ratio of children and adolescents decreases due to declining fertility rate (Matras, 1977; Rosniza \& Asmah, 2010). This will affect the socioeconomic development in terms of education, health, transportation, finance, and housing (Matras, 1977). In fact, population composition is associated social patterns, which are influenced by changes in age and gender structure in a society and nation. In the study of demographic, changes in the age distribution affects a country's development. The age distribution of a population is influenced by changes in fertility and mortality rates (Goldstein, 2009). The demographic transition due to the decline in 
birth and death rates contribute to ageing population, especially in the developed countries (United Nations, 2019).

However, in a developing country such as Malaysia, population ageing affects the socioeconomic because of declining fertility rate since the 1960s. According to the Department of Statistics, Malaysia is also facing the growing elderly population issues since out of 28.3 million Malaysians in 2010, those who aged 60 and above makes up 7.9\% of the country's population (2011). In 2017, those who aged 65 and above was estimated to be two million, an increase by $0.2 \%$ from 2016. Malaysia is expected to experience elderly population growth up to $7 \%$ of the country's population by 2020 (Department of Statistics Malaysia, 2017). According to Ju and Gones (1989), the growth of the elderly population in Malaysia or other Asian countries is faster compared to other age groups. This can cause a huge impact on the country and must be dealt with so that this group can contribute to the country's development (Teerawichitchainan \& Knodel, 2018). United Nations reported that the increase in the ageing population becomes a major issue in the aspects of healthcare and social support (Kesby, 2017).

Changes in demographics and family structure have resulted in the lack of family support for the elders. Nowadays, the younger generation prefer to have a smaller family, some do not plan to get married and some prefer not to live with their old parents, all these reduce the amount of support can be provided to the elders (National Institutes on Aging in the National Institute of Health, 2011). The migration of children to cities has affected family support for their elderly parents and their wellbeing (WHO, 2012). An increasing elderly population is caused by the growth of life expectancy and improvement in healthcare aspects (Farhah Hanun Ngah, 2017). The life expectancy of population increases due to better nutrition, medical advancement, hygiene, education, healthcare, and economic wellbeing (UNFPA, 2012). Indeed, the elderly population has experienced growth in socioeconomic status, especially in healthcare.

\section{Trends of ageing population in Malaysia}

Malaysia is expected to be an aged nation by 2030 when $15 \%$ of the population are 60 years and above. The ageing population is expanding over almost four decades from 316,858 in 1970 to $1,427,340$ in 2017 . The number of elderly people is expected to keep growing up to $7.8 \%$ by 2020 (Neville, 1992). Figure 1 shows the number of elders in Malaysia from 1970 to 2019, however the value in 2019 is only an estimation. Figure 1 shows the increase in the number of elders from 1970 to 2019, with annual increment of 546,000 in 1970 to 3.4 million in 2019. On the contrary, in 1970, only $5.2 \%$ of the population are the elders, but in 2019 the elderly population had increased to 10.3\%. When it comes to states in Malaysia, the Department of Statistics (2019a) stated Perak has reached the 'old' status when the people 60 and above reached $15.3 \%$ of the state population in 2020 (MyMetro, 31 October 2019).

Statistics shows that the life expectancy of Malaysians increases in line with socioeconomic status and medical advancement. The death rate of all age groups declines over the years because of improvements in healthcare and in 2020, the life expectancy of the Malaysian population is expected to increase to 80 (Abdul Aziz Jemain, 2000). In 2018, the life expectancy of Malaysians was 75 (Department of Statistics Malaysia, 2018). According to the Department of Statistics Malaysia (2018), a newborn in 2018 was expected to live within 75 years on average, until 2093. Besides, Malaysian males and Malaysian females at the age of 65 are expected to live for 15.0 and 17.2 more years, respectively. The increasing elderly population in Malaysia is due 
to lower fertility rate. According to the Department of Statistics Malaysia (2019), the crude birth rate is 15.5 per 1,000 populations. Meanwhile, the total fertility rate per woman aged 15 to 49 was 1.8 births. The fertility rate in Malaysia since 2013 is below 2.1, which indicates that the average babies born per woman throughout her reproductive age is insufficient to replace herself and her partner. The decline in the fertility rate has affected labour market and family support.

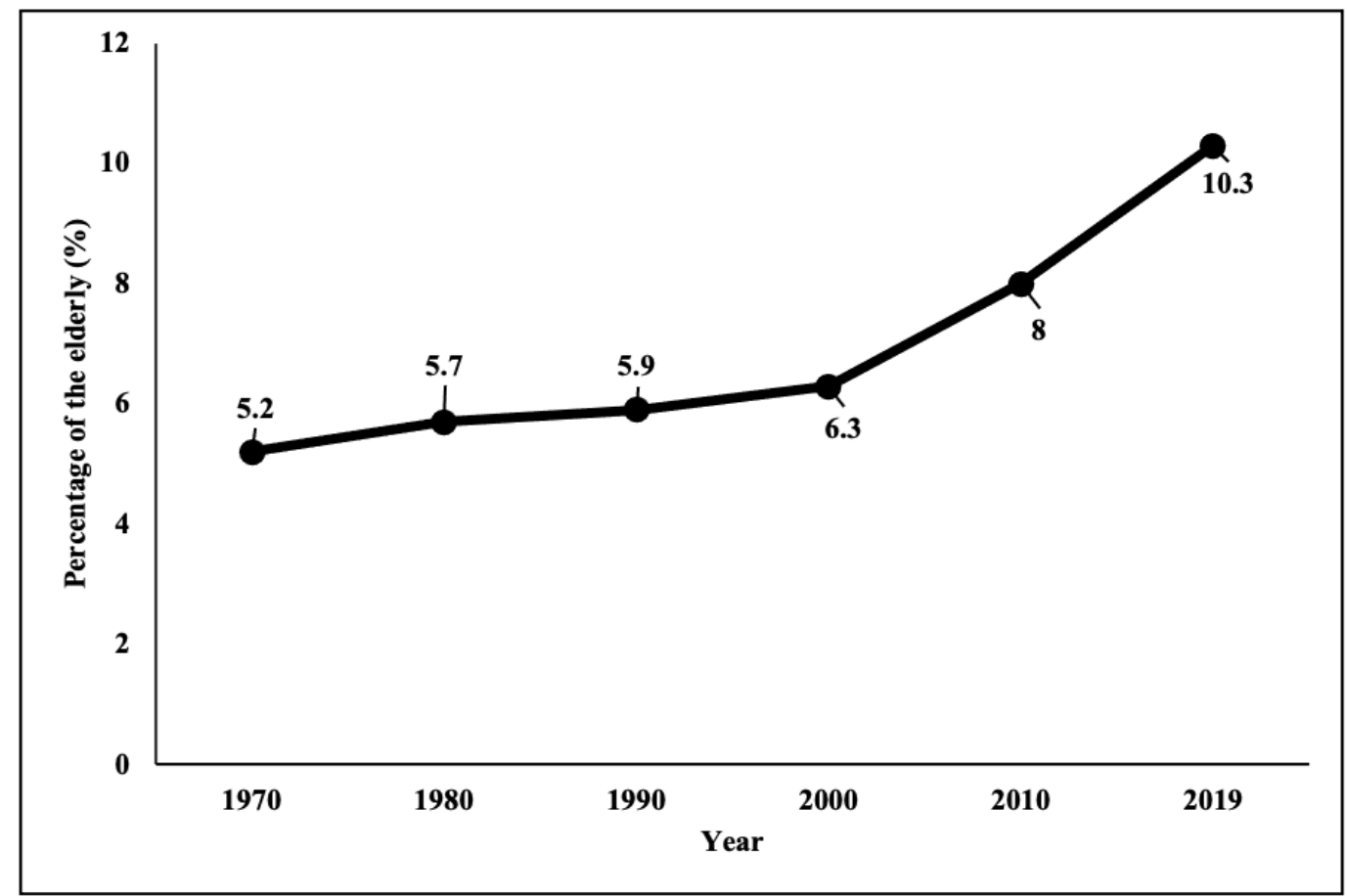

Source: Department of Statistics Malaysia (2019a)

Figure 1: Percentage of the elders in Malaysia, 1970-2019

Moreover, the increase in the number of elders affects the dependency ratio of the population aged 65 and above. This shows that the working class is now facing the burden to care for the elders, which is expected to increase in the future. The dependency ratio is the ratio of dependents to 100 people in the working-age group. The total dependency ratio consist of youth dependency ratio (those below 15) and old-age dependency ratio (65 and above) (Department of Statistics Malaysia, 2017). Figure 2 shows a decreasing dependency ratio of 92.3 per 100 working people (15-64 years old) in 1970 to 44.0 per 100 working people (15-64 years old) in 2015 . The dependency ratio decreased to $43.0 \%$. The ratio of young dependents aged 0 to 14 shows a decline from 86.3 per 100 working people (15-64 years old) in 1970 to 35.3 per 100 working people in 2010 , recording a decrease by $32.6 \%$. The decline in youth dependency ratio is because of lower number of people aged 15 and below due to declining fertility rate in Malaysia. Contrary to the old-age dependency ratio, this increased from 6.0 per 100 working people (15-64 years old) in 1970 to 8.7 per 100 working people in 2016 , indicating the increase by $8.0 \%$ within the period (1970-2016). 


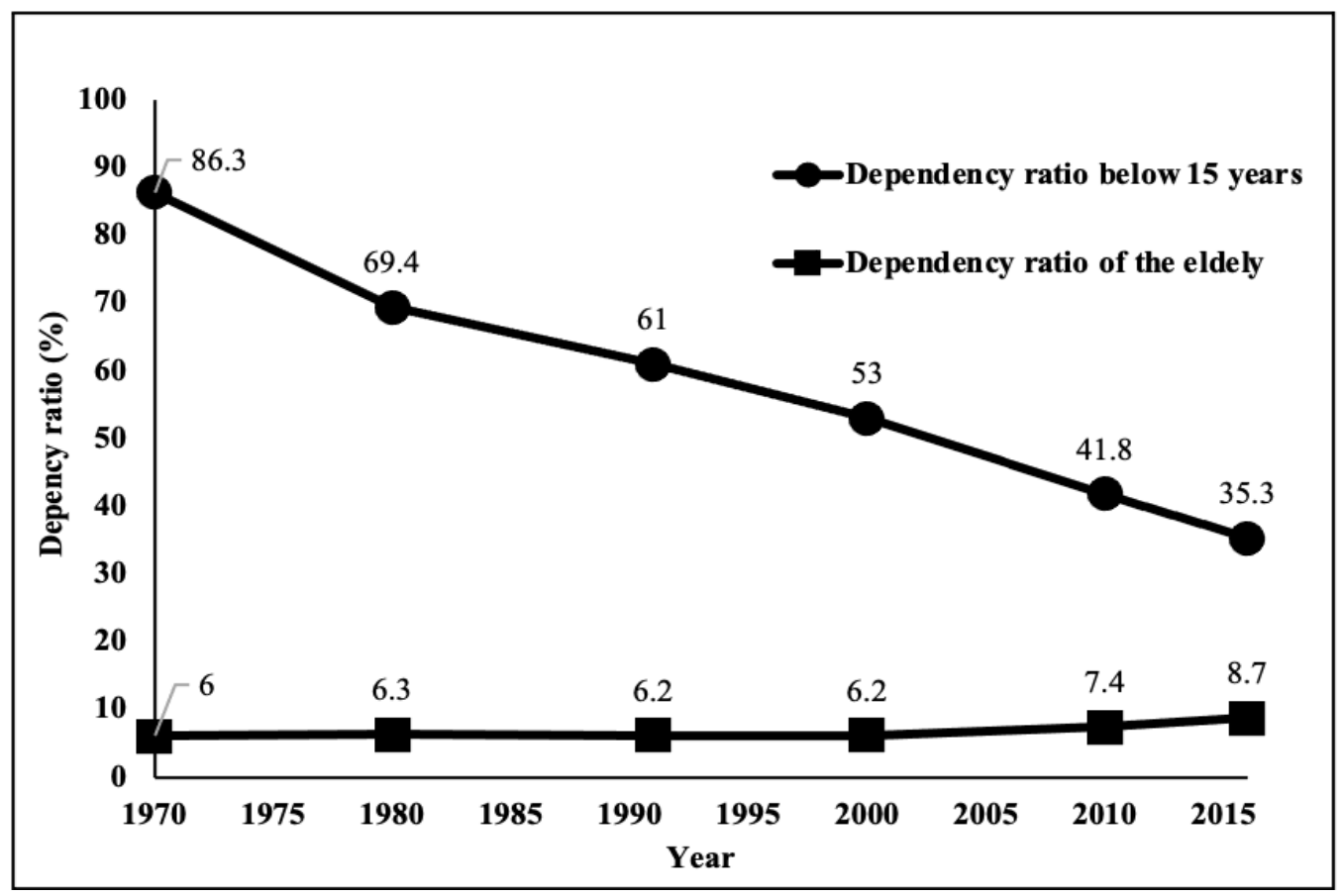

Source: Department of Statistics Malaysia $(1975 ; 1984 ; 1995 ; 2001 ; 2011 ; 2017)$.

Figure 2: Dependency ratio of the population in Malaysia, 1970-2015.

Low fertility rate can increase or reduce the lifespan of a human. This leads to population ageing issues and efforts to address those issues in terms of healthcare, housing, general care, lack of income, relationship and family support to manage the life of the elders. The community should be prepared to accommodate growing number of elders in the community and take steps to address this issue, especially elderly males. This is because more elderly males who have problems to manage themselves, especially when their wife have died. However, more elders are now aware of these issues of self-care and some have become productive members of the society. One concern is that children are not willing to live with their parents, leaving the elders to live alone without any help from the family, particularly in healthcare and nutritional needs. This issue becomes more evident in the developed and developing countries, since the phenomenon of older people living alone in big cities has become a norm.

\section{Implementation of policies for the elders in Malaysia}

By 2030, Malaysia will become an 'old country' with a population of 60 and above makes up 15\% of the country's population. Issues of ageing population such as health, particularly mental health, savings, labour, and social support for the elders have to be addressed. To cope with an aged nation, Malaysia has implemented several policies and programmes aimed at caring for the elders and for the sake of their welfare. One of the policies implemented is the National Policy on Older Persons (Dasar Warga Tua Negara, DWTN) in 1995, which was later improved and renamed as Dasar Warga Emas Negara (DWEN) in 2011.

DWTN that was launched in 1995 reflects the government's commitment to create a prosperous and dignified elderly population, to enable this group to enjoy every opportunity during 
their later life and receive care and protection (Ministry of Women Development, Family and Community Development, 2011; Aziz Shafie et al., 2004). There are three objectives outlined in DWTN; 1) enhancing the dignity of the elders in the family, community and nation, 2) fostering the elders' potential so that they remain active and productive in the course of the country's development as well as creating opportunities to help them survive independently, and 3) provide facilities that ensure the care and protection of the elders (Ministry of Women, Family, and Community Development, 2011; Aziz Shafie et al., 2004; Tengku Aizan Hamid \& Nurizan Yahaya, 2008). To ensure successful implementation of DWTN, relevant agencies had initiated integrated and comprehensive efforts towards this cause. There are 11 action plans under DWTN, one of them is related to the family support, which aims to ensure that the elders stay with their family. Family support focuses on living arrangement and this contributes to the wellbeing of the elders. Undoubtedly, the elders need attention and support from their families, local communities and leaders to help them to live in their twilight years (Suhana Saad, 2001).

Recognising the fact that the number of elders keeps increasing over the years, the Cabinet approved Dasar Warga Emas Negara (DWEN) that was proposed by the Ministry of Women, Family and Community Development on $5^{\text {th }}$ January 2011 (Department of Social Welfare, 2013). The policy is the re-evaluation and improvement of The National Policy for Older Persons DWTN. The philosophy of DWEN is to recognise the elders as citizens with diverse backgrounds and experiences, therefore they have the right to enjoy a prosperous life, be respected and keep contributing to national development. DWEN has six objectives; 1) developing societies that are concerned with the ageing phenomenon and can cope with old age, 2) facilitating access to lifelong learning among elders, families, and communities, 3) ensuring the elders are safe and protected, 4) establishing an effective and integrated senior citizen delivery system, 5) increasing the elders' involvement in the community, and 6) promoting the use of research findings as a basis for planning, monitoring, and evaluating programmes for the elders (Ministry of Women, Family and Community Development, 2011a).

In addition, a centre known as the Senior Citizens Activity Centre (PAWE) was established under DWEN. PAWE was established in collaboration with several NGOs and it needs to be improved to ensure the care of the elders while they family members are out working. PAWE is also a place where the elders can be self-reliant and interact with their elderly friends and the local community. Furthermore, the elders can gain knowledge and other benefits from the establishment of PAWE. For instance, PAWE serves as a community centre for the elders to socialise so they will not feel isolated or experience the empty nest syndrome. It is hoped that the government can establish more PAWE in rural areas so that children can bring their elderly parents in the morning to this centre and pick them up after work. Some of the activities carried out at PAWE are related to health, sports, recreation, therapy or rehabilitation, training/courses religion, and volunteering services (Department of Social Welfare, 2013a). PAWE was established to prevent loneliness and depression among the elders and prevent them from being sent to welfare centres.

In line with the increasing life expectancy in Malaysia, Dasar Kesihatan Warga Emas Negara (DKWEN) was established in 1995. The policy was introduced to ensure healthy, active and productive ageing by empowering the elders, families, and communities with the knowledge, skills, and environment besides providing optimal healthcare services in many sectors. The purpose of DKWEN is to ensure the elders enjoy optimal health via fitness and health-related services. It also considers the elders' changes in health needs over time (Ministry of Women, Family and Community Development, 2012). DKWEN outlines four objectives; 1) improving the elders' state of health, 2) encouraging the elders' participation in health and disease prevention 
activities throughout their whole life, 3 ) providing healthcare services that are age-friendly, costeffective, affordable, culturally appropriate, gender-neutral, and sustainable, and 4) supporting an environment that enables independent living (local ageing) (Ministry of Women, Family and Community Development, 2012).

Moreover, health professionals are required to review current policies to improve the readiness of the population to care for the elders (New Straits Times, 2019a). Furthermore, despite many initiatives to assist the elders, Malaysia still does not have enough healthcare facilities to accommodate the growing elderly population. In honour of the elders in Malaysia, the government has announced Hari Sambutan Warga Emas Kebangsaan in 1992 to be celebrated on $1^{\text {st }}$ October every year (Department of Social Welfare, 2016). This is to celebrate the elders and reminds everyone that the elders should not be a burden to anyone, especially to their loved ones. The activities organised on this special day include physical activities and health talks to ensure the elders remain active and undergo healthy ageing.

In fact, it is proven that the government is committed and aware of the increasing number of elders in Malaysia. However, there is no ordinance that mandates children to take care of their elderly parents and the need to provide support in terms of economic, physical and social supports. This bill is necessary to ensure the wellbeing of the elders and prevent them from experiencing empty nest syndrome and depression. Empty nest syndrome refers to the feeling of loneliness experienced by the elders especially those who live alone after their children leave the house (JunE et al., 2015). They children leave their parents' house due to marriage, further education, and work (Abraham, 2012)

\section{The Issue of elderly neglect in the Malaysian newspapers}

Although Malaysia has implemented policies regarding the welfare of the elders, some have been neglected and abandoned, especially by their own family. Studies have highlighted the implications of this phenomenon that plagues the elderly group, which have been reported by the media. This includes children who neglect their elderly parents, send their parents to welfare homes, financial abuse, leave their elderly parents in the hospital and even let their parents live alone without paying attention to their necessities. This shows to what extent the elders are being dismissed and marginalised in their golden age, indicating how much family values has faded.

Today's media features a lot of heart-breaking stories about the elders who are plagued with neglect and abandonment by their own family. The terms 'anak derhaka' and 'Si Tanggang Moden' reflect the scenarios where children seldomly care for their elderly parents (MyMetro, 9.7.2017; MStar, 11.3. 2016; Jal Zabdi Mohd Yusoff, 2009; Kosmo, 22.11.2014; Berita Harian, 29.8.2012, 21.9.2012). The Sunday News (18.9.2011) reported the story of children chasing their parents away after claiming their parents' property and forcing their parents to live in a welfare home. The issue of overcrowding in the welfare centres or old folk's homes has been addressed in the media (Kosmo, 9.11.2013). There are also children who 'discard' their sick parents, the whole family are Muslims, in the non-Muslim nursing home, making it difficult for the parents to perform their religious obligations (Berita Harian, 2.7.2010).

There are reports of some children who have made hospitals the 'dumping ground' for elderly parents, changing hospitals of their original roles into welfare centres (New Strait Times, 29.9.2011). The incidents of elderly parents 'living' in hospitals occur in big cities such as Penang and Kuala Lumpur. Hospitals have become a centre for children to 'leave behind' their elderly 
parents with the excuse of being busy and having no time to manage their parents. Some children purposely register themselves using fake information and phone contacts when their parents are admitted to the hospitals so that the health authorities cannot trace them. This predicament is a sign that some elders are being neglected by their children and family members. In fact, there is a case reported in Harian Metro (2.11.2006) about the elderly parents who had been killed by their own children in Japan because the children were no longer able to care for their old and sick parents. Japan is the oldest population in the world, hence, the issues of caring for elders and suicide rate among the elders aged 60 and above are high.

Besides, there is story of an elderly woman living alone despite having many children in the local newspaper (Utusan Consumer, July-August 2011). The children only send their money but rarely visit her even she is living alone. Indeed, single parents are often hit by the empty nest syndrome when more and more children migrate to the city (Berita Harian, 22.9.2011). The children leave their parents' home due to marriage, furher study, working, creating an empty nest with only the elderly parents left behind (Abraham, 2012). According to a United Nations (2005), the elders in developed countries tend to experience the empty nest syndrome, especially when their youngest child leaves home to further their education, for working or du to marriage (United Nations, 2005). They were left unattended, and some of the elders even became homeless. Children today are deemed to be only pursuing wealth and luxury without considering their family responsibility to their parents

\section{Discussion and recommendations}

In 1995, Singapore passed the Maintenance of Parents Act (Mehta, 2006) into law. The Act aims to ensure the children take care their parents' welfare by providing monthly expenses, food and clothing, as well as healthcare facilities (Rozario \& Kay, 2014). Those who disobey the law shall be fined. Also, Singapore has established an agency that provides accommodation for elderly parents. The agency provides free services to elderly parents who complain they have been neglected by their children. The purpose of this agency is to reiterate that if parents have raised their children, then the children should return the favour by shouldering the responsibility to support their parents without solely relying on the government to support and care for the elderly parents.

The approach taken by Singapore should be adopted in Malaysia so that children will be more aware to care for their elderly parents and this will hinder the children from neglecting their responsibility since the number of cases reported in the local media concerning elderly parents being abandoned has increased. Not only that, China also passed a law effective $1^{\text {st }}$ July 2013 regarding protection and welfare of the elders (Berita Harian, 2.7.2013). On $1^{\text {st }}$ May 2016, the City of Shanghai announced a drastic move whereby children are required to visit their parents more often even if the parents are living in a foster home (BH Online, 9.4.2016). This is a reminder for the family members and children to not leave the elderly parents at the welfare home without paying regular visits. During the visit, children are required to provide financial and emotional support. The law states that those children who fail to visit their elderly parents and leave them alone without any support, they are liable to fine. Therefore, the author hope Malaysia country will enact a legislation to ensure children take care of their parents' welfare rather than leave the elders alone to reduce the influx of elderly parents living in welfare homes and care centres elders. In addition, the Ministry of Women, Family, and Community Development needs to address issues 
related to the elders, especially when the number of elderly women is greater than elderly men. So, the responsible authority should give more focus to elderly women, especially those living alone. As there are more elders, the issues concerning them such as abuse and abandonment become a norm. Hence, a legislation that protects the elders should be enacted to ensure the wellbeing of this group.

\section{Conclusion}

In conclusion, looking at the current policies and initiatives, Malaysia is prepared to deal with the issue of ageing population or 'old' nation status. However, the author hope there is a specific bill to be passed into law in Malaysia to ensure the children to be more concerned with their parents' wellbeing and do not leave their parents living alone to prevent overcrowding in the welfare or old folk's homes, as reported by local media. It is time for the Malaysian government to approve a bill or enact legislation to address the issue of elderly neglect by the children. The legislation is aimed to ensure children care for the parents and they do not abandon their responsibility to look after their parents, as has been implemented in Singapore and China. Children who care for their elderly parents and live with them have to safeguard the wellbeing of their elderly parents. All parties should be aware that ageing is a major challenge to the country. This requires due care, commitment and action by all parties, including the community to enable healthy ageing among the elders. Considering many cases of elders being abandoned by their own family, it is time for the author to develop a comprehensive policy on the elders that allows the government, NGOs, the community and individuals to take part and act in caring for the elders. A legislation that protects the elders is crucial as more and more children are neglecting the welfare of their parents. Some have even left their parents stranded in welfare homes. Looking at the healthcare perspective, the government has provided healthcare facilities to ensure that the elders can take care of their health. However, the availability of health facilities are still limited, and not many elders living in rural areas have access to healthcare. Furthermore, many elders in the rural areas are not aware of the importance of undergoing medical check-ups to detect the early signs of any chronic diseases. Therefore, the rural community have to be exposed to better healthcare initiatives so that the elders living there can remain active and productive in their golden age.

\section{Acknowledgement}

The author would like to thank Universiti Sains Malaysia for funding this project through Short Term Grant (304/PJJAUH/6315265).

\section{Reference}

Abdul Aziz Jemain. (2000). Menyurih Perubahan Melunjur Penuaan: Kajian Kes Populasi Semenanjung Malaysia. Dlm. Abdul Aziz Jemain, Rahimah Abdul Aziz \& Lukman Z. Mohamad. (ed). Warga Tua: Isu dan Fenomena. Bangi: Universiti Kebangsaan Malaysia. 53-76.

Abraham, S. (2012). Ageing Successfully for Manageing Empty Nest Syndrome. HelpAge IndiaResearch \& Development Journal, 18(2), 39-41. 
Aziz Shafie, Usman Haji Yaakob \& Suriati Ghazali. (2004). Penjagaan sosial dan kesejahteraan hidup warga tua di negeri Perlis. Jurnal Kerja Sosial Malaysia. 3, 3-28.

Berita Harian. Bapa kaya anak hidup kesepian: Sindrom "sarang kosong" meningkat berikutan generasi muda hijrah ke bandar. Sept 22, 2011.

Berita Harian. Buang bapa di rumah jagaan bukan Islam: Warga emas mohon tempat lebih selesa bagi mudah ibadat. July 2, 2010.

Berita Harian. Denda jika abai ibu bapa: China lulus undang-undang untuk jaga warga tua. July 2, 2013.

Berita Harian. Hukuman Buat Si Tanggang Moden. August 29, 2012.

Berita Harian. Negara perlu 700 pakar geriatrik menjelang 2020. August 12, 2015.

Berita Harian. Sistem kesihatan kena ambil kira fasa negara tua. May 21, 2015

Berita Harian. Susu dibalas tuba: Anak derhaka buang ibu bapa. Sept 21, 2012.

BH Online. Shanghai umum langkah pastikan anak lawat ibu bapa. 9.4.2016. Retrieved from: https://www.bharian.com.my/node/142058. Date access: Jan 5, 2020

Department of Social Welfare. Dasar Warga Emas Negara. Retrieved from: http://www.jkm.gov.my/jkm/index.php?r=portal/left\&id=WjFUdFBURTV0Zis0N0NxY m05Qk9XQT09

Department of Social Welfare. Dasar Warga Emas Negara. Retrieved from: http://www.jkm.gov.my/content.php?pagename=dasar warga_emas_negara\&lang=bm.

Department of Social Welfare. Unit Penyayang Warga Emas. Retrieved from: http://www.jkm.gov.my/content.php?pagename=unit_penyayang_warga_emas\&lang=bm

Department of Statistics Malaysia. (1984). Administrative District Population Report. Kuala Lumpur.

Department of Statistics Malaysia. (1995). General Report: Population Census of Malaysia 1990. Kuala Lumpur.

Department of Statistics Malaysia. (2001). Population Distribution and Basic Demographic Characteristics 2000. Putrajaya.

Department of Statistics Malaysia. (2011). Population Distribution and Basic Demographic Characteristics 2010. Putrajaya.

Department of Statistics Malaysia. (2017). Current Population Estimates Malaysia 2017. Putrajaya.

Department of Statistics Malaysia. (2018). Abridged Life Tables Malaysia 2016-2018. Putrajaya. Department of Statistics Malaysia. (2019). Vital Statistics Malaysia 2019. Putrajaya.

Department of Statistics Malaysia. General Report: Population Census of Malaysia 1970. Vol. 2. Kuala Lumpur, 1975.

Department of Statistics Malaysia. Quick Facts Vol.8/2019. Retrieved from: https://www.mycensus.gov.my/banci/www/index.php?\&id=3\&page_id=36

Dhillon, P., Ladusingh, L., \& Agrawal, G. (2016). Ageing and changing patterns in familial structure for older persons in India: A decomposition analysis. Quality in Ageing and Older Adults, 17 (2), pg. 83-96. DOI: 10.1108/QAOA-10-2014-0024.

Farhah Hanun Ngah \& Denise Koh Choon Lian. (2017). Kualiti hidup dan aktiviti fizikal warga emas. Geografia-Malaysian Journal of Society and Space, 13(2), 44-53.

Goldstein, J.R. (2009). How Population Age. In: Uhlenberg, P (ed). International Handbook of Population Ageing. Volume 1. Springer: 7-18.

Harian Metro. Jepun hadapi masalah orang tua. November 2, 2006. 
Jal Zabdi Mohd Yusoff. (2020). Jenayah dalam keluarga: Penderaan dan pengabaian warga tua di Malaysia. International Conference on Corporate Law (ICCL), 1-3 June 2009. Surabaya, Indonesia. Retrieved from: http://repo.uum.edu.my/1144/1/ Jal_Zabdi_Mohd_Yusoff.pdf.

Ju, C. A., \& Jones, G. (1989). Ageing in Asean: Its Socioeconomic Consequences. Singapura: Institute of Southeast Asian Studies.

Jun-E. L., Peng, Y., Yong, L. W., Xue, P. D., \& Shuang, Q. C. (2015). Living experience and care needs of Chinese empty-nest elderly people in urban communities in Beijing, China: A qualitative study. International Journal of Nursing Sciences, 2, 15-22.

Kesby, A. (2017). Narratives of Ageing and the Human Rights of Older Persons. Human Rights Review, 18(4), 371-393. DOI: 10.1007/s12142-017-0470-6.

Kosmo. Ibu ditinggalkan bersama sebuah beg, plastik sampah: 4 anak buang ibu tua. November 22, 2014.

Kosmo. Mon negeri warga emas. June 6, 2013.

Matras, J. (1977). Introduction to Population: A Sociological Approach. New Jersey: Prentice Hall.

Mehta, K. K. (2006). A Critical Review of Singapore's Policies Aimed at Supporting Families Caring for Older Members. Journal of Ageing \& Social Policy, 18(3-4), 43-57.

Ministry of Finance. (2014). Bajet 2012. http://www.treasury.gov.my/index.php?option=com_ content \&view=article \&id=2543:ucapan-bajet-2012\&catid=256\&lang=ms\&Itemid=2472

Ministry of Women, Family and Community Development. (2011). Dasar Warga Tua Negara. Retrieved from: http://www.kpwkm.gov.my/documents/10156/616c1f4a-71ca-4a209837-f1f52be30934

Ministry of Women, Family and Community Development. (2011a). Dasar Warga Emas Negara. Retrieved from: http://www.kpwkm.gov.my/dasar1?p_p_id

Ministry of Women, Family and Community Development. (2011b). Pelan Tindakan Dasar Warga Emas Negara. Retrieved from: http://www.kpwkm.gov.my/dasar1?p_p_id

Ministry of Women, Family and Community Development. (2012). Dasar Kesihatan Warga Emas Negara. Retrieved from: http://www.kpwkm.gov.my/dasar1?p_p_id

Ministry of Women, Family and Community Development. (2012a). Pelan Tindakan Dasar Kesihatan Warga Emas Negara. Retrieved from: http://www.kpwkm.gov.my/ dasar1?p_p_id

MStar. Semakin tua, semakin diabai. 11 March 2016. Retrieved from https://www.mstar.com.my/lokal/semasa/2016/03/11/semakin-tua-semakin-diabai. Date access: Jan 1, 2021

MyMetro. Kian ramai warga tua didera. 9 July 2017 Retrieved from: https://www.hmetro.com.my/sihat/2017/07/243481/kian-ramai-warga-tua-didera. Date access: Jan 10, 2021

MyMetro. Perak negeri tertua 2020. 31 Oct 2019. Retrieved from: https://www.hmetro.com.my/mutakhir/2019/10/512368/perak-negeri-tertua-2020. Date access: Jan 10, 2021

MyMetro. Tergamak abai ibu bapa. 15 Apr 2016. Retrieved from https://www.hmetro.com.my/node/130699. Date access: Jan 10, 2021

National Institutes on Ageing \& National Institute of Health. (2011). Global Health and Ageing. U.S: Department of Health and Human Services. 
Neville, W. (1992). The Dynamics of Population Ageing into the Twenty-First Century: ASEAN and Selected Countries of Pacific Asia. ASEAN Economic Bulletin, 9(1), 4-21.

New Straits Times. Ageing population a test for Asean govts. 17 December 2019. Retrieved from:https://www.nst.com.my/world/region/2019/12/548599/ageing-population-testasean-govts. Date access: Jan 1, 2020

New Straits Times. Are we ready for ageing Malaysia. 15 December 2019. Retrieved from:https:/www.nst.com.my/news/exclusive/2019/12/548012/are-we-ready-ageingmalaysia. Date access: November 11, 2020.

New Straits Times. Don't treat like a nursing home for old folk. September 29, 2011.

Nur Syakiran Akmal Ismail, Norehan Abdullah, Kalthum Hassan, Shamzaeffa Samsudin, Ummu Atiyah Ahmad Zakuan, Rohana Yusof, \& Nurzalyna Mohamed Zaki. (2017). Kesejahteraan hidup warga emas: Perancangan berasaskan gender. Geografia-Malaysia Journal of Society and Space, 13(3), 75-85.

Restrepo, H. E., \& Rozental, M. (1994). The Social Impact of Aging Population: Some Major Issues. Social Science Medicine, 39(9), 1323-1338.

Rosniza Aznie Che Rose \& Asmah Ahmad. (2010). Peningkatan pendidikan menjejaskan fertiliti penduduk tempatan: Konfirmasi dari pembangunan Besut Baru, Terengganu. GeografiaMalaysian Journal of Society and Space, 6(2), 51-62.

Rozario, P.A., \& Kay, L. (2014). Contested Representations of a Family Responsibility Law: The Case of Singapore's Maintenance of Parents Act of 1995. Journal of Policy Practice. 13, 118-132.

Suhana Saad. (2001). Peranan Keluarga dalam Merealisasikan Dasar Warga Tua Negara. Dlm. Abdul Aziz Jemain, Lukman Z. Mohamad dan Wan Norsiah Mohamed. (ed). Jaminan Sosial Warga Tua. Selangor: Prentice Hall, Pearson Education Malaysia Sdn. Bhd: 25-36.

Teerawichitchainan, B., \& Knodel, J. Long-Term Care Needs in the Context of Poverty and Population Ageing: the Case of Older Persons in Myanmar. (2018). Journal of CrossCultural Gerontology, 33(2), 143-162. DOI: 10.1007/s10823-017-9336-2

Tengku Aizan Hamid \& Nurizan Yahaya. (2008). National Policy for the Elderly in Malaysia: Achievements and Challenges. In Lee, H.G. (ed). Ageing in Southeast and East Asia: Family, Social Protection and Policy Challenges. Singapore: Institute of Southeast Asian Studies: 108-133.

United Nations Population Fund (UNFPA). (2012). Ageing in the Twenty-First Century: A Celebration and A Challenge. London.

United Nations. (2005). Living Arrangements of Older Persons Around the World. New York: Department of Economic and Social Affairs Population Division.

United Nations. (2011). World Population Prospects: The 2010 Revision. Vol 1, Comprehensive Tables. New York.

United Nations. (2019). World Population Prospect 2019, Volume 11: Demographic Profiles. New York: Department of Economic and Social Affairs.

Utusan Konsumer. Should Malaysian Compelled to Take Care of Their Ageing Parents? I took Care of 10 Children, But Now the 10 Cannot Take Care of 1. Julai-Ogos 2011.

World Health Organization (WHO). (2012). Connecting and caring: innovations for healthy ageing. Bulletin of the World Health Organization, 90, 162-163. 